\title{
Functional capacity and language evaluation among elderly residents in Manaus/AM, Brazil
}

\begin{abstract}
The aim of this article was to assess the functional capacity and language on elderly in Manaus/AM, Brazil. It is a cross-sectional study conducted from August to December 2013, with 646 interviewed aged 60 or more. This evaluation was based on the validated analytical tools, namely, activities of daily living (ADL) and Mini Mental State Examination (MMSE). Descriptive analysis was performed using central tendency and dispersion measures for continuous variables and frequency distributions for categorical variables and the prevalence of self-reported language disorders was estimated. To verify the presence of statistically significant differences it was used Fisher's exact test, odds ratio (OR) and binary logistic regression, considering the significance level of $5 \%(p \leq 0.05)$. The logistic regression model noted that the chance of the elderly present the altered language is $31 \%$ higher if illiterate. Being female increases the chance by $85 \%$. Being dependent for ADL increases by $239 \%$ chance of having a result of changed language, and with change in MMSE results, provides an opportunity to be increased by more than 30 times. Significant results were found when correlated the outcomes studied. Low MMSE score was associated with increased risk of incident disability in ADLs.
\end{abstract}

Keywords: aged, language, activities of daily living, mental health
Volume 2 Issue I - 2017

\author{
JS Vasconcelos,' KGM Crispim, 'AP Ferreira, ${ }^{2}$ \\ JBL Filho ${ }^{3}$ \\ 'Research Nucleus and Technological Innovation, Metropolitan \\ University of Manaus, Brazil \\ ${ }^{2}$ Department of Human Rights, Sergio Arouca National School \\ of Public Health, Brazil \\ ${ }^{3}$ EvandroChagas National Institute of Infectology, Brazil
}

\begin{abstract}
Correspondence: Karla Geovanna Moraes Crispim, Research Nucleus and Technological Innovation, Metropolitan University of Manaus, Brazil, Email karlag_crispim@hotmail.com
\end{abstract}

Received: May 27, 2017 | Published: August 15, 2017
Abbreviations: ADL, activities of daily living; MMSE, mini mental state examination; OR, odds ratio

\section{Introduction}

Population ageing describes the changes in the age structure, thus is an inevitable effect of so-called demographic revolution in which there has been a shift from extensive to intensive demographic reproductions, characterized by low birth and death rates respectively to prolonging human life. ${ }^{1,2}$ This process has been occurring in a very rapid and progressive way, especially in the developing countries, in which Brazil fits in..$^{3,4}$

It is estimated that, in 2025 , Brazil will be the sixth country in the world regarding the number of elderly. In the Northern Region, this index is still the lowest in relation to the other country regions; however, it has been increasing over the years. ${ }^{5}$

Brazil, despite significant advances, is still a country with great social inequalities. During the course of life, the Brazilian elderly witnessed a country with great social contradictions ${ }^{6}$ which characterizes this group as vulnerable to social determinants of health.

The Brazilian population is aging without the necessary political and social interventions for a better quality of life, since faced with an economic crisis such age group is susceptible to acquire diseases, not having access to preventive measures, nor even to treatment. With the increase in the number of elderly people and the prolongation of life expectancy, concern about functional capacity has been increasing in several areas. ${ }^{7}$ In order to know the degree of independence or dependence in elderly, it is necessary to perform a functional evaluation, which is usually performed through the evaluation of Daily Life Activities performance. This evaluation is relevant and, being directly associated with indicators of quality of life in the elderly. ${ }^{8}$
In addition, communication is very important for the human being, at any age, because through it we can carry out social and affective interaction. ${ }^{9}$ For this, we make use of language. However, studies on language in the senescence area, in general, describe the diseases and their sequels, being recent studies with healthy elderly people. ${ }^{10,11}$ According to Garcia and Mansur ${ }^{11}$ the evaluation of the language of healthy elderly people has shown that when there is decline, it is not similar, because some factors remain preserved and others change.

Population-based epidemiological studies, that is, those studies that investigate the living conditions in the elderly provide basic information for public health, but are still rare in Brazil, especially in the North and Northeast regions. ${ }^{12,13}$ These studies, in order to know the epidemiological problems for this population, provide an opportunity to increase knowledge about health problems and, thus, to allow the distribution of risk factors and people's understanding of their health status. ${ }^{10}$

It is in this context that analyzing the relationship between functional capacity and language become essential to determine the conditions of life and health of the elderly, subsidizing the effectiveness and efficiency of the interventions proposed in the elderly, fundamental aspects for a good quality of life on this group. In view of the above, this study aims to analyze the correlation between functional capacity and language of elderly residents in the Manaus community /AM.

\section{Discussion}

The present research reveals that the majority of elderly surveyed were independent $(96 \%)$ in ADL. However, it is not possible to generalize the data obtained to an entire elderly population because the research was performed with healthy one. Studies on functional capacity with institutionalized elderly indicate a greater dependence on elderly people living in households $\mathrm{Karsch}^{14}$ observed independence in $41.6 \%(\mathrm{n}=52)$, partial dependence in $15.2 \%(\mathrm{n}=19)$, and total 
dependency in 43.2\% ( $n=54)$. Dias et al. (2015) identified $40 \%$ of elderly dependent in their study, with a moderate correlation between functional capacity and low income.

The functional capacity in the elderly affects an important indicator in the degree of independence, as well as the need for preventive measures, fundamental in the actions of health promotion, which abbreviate the mechanisms that affect the decline of the elderly's ability to perform the different daily physical and mental functions. Consequently, the limitations, dependence/independence, adaptations in the accomplishment of many activities by the elderly can result from the aging process or the appearance/evolution of chronicdegenerative diseases.

In relation to the demographic variables, the research brings results compatible with other studies related to aging. The prevalent age group of 60-64 years, female predominance, race/white color, marital status with higher number of married couples followed by widows. ${ }^{15}$

Mello \& Barbosa ${ }^{16}$ when doing a systematic review of Brazilian investigations that used the MEEM, found 74 articles that applied the instrument in the elderly. The authors concluded that the MMSE remains the instrument of screening of the most used cognitive status in this population.

Cognitive decline is related to different biopsychosocial variables in the elderly. ${ }^{17} \mathrm{~A}$ factor that contributes substantially to the differences in the performance of cognitive tests in several populations is schooling. ${ }^{16,18}$ The relationship between schooling and dementia is presented in a complex way in the literature. The number of years of study has been considered both as a factor of neuronal protection and as an element of diagnostic confusion, since the performance of individuals tested with cognitive assessment instruments is strongly influenced by schooling. ${ }^{19,20}$ According to Converso \& Iartielli ${ }^{21}$ the MEEM specificity and sensitivity is limited when the test is applied in populations with little or no formal schooling. In fact, in the detection of dementia in adults with good schooling, this instrument has the sensitivity and confidence measures of $92 \%$ to $100 \%{ }^{22}$

In order to verify the association between functional capacity, language, sex and schooling, crosses between these variables were performed. In the relationship between schooling and language, $33.0 \%$ of the illiterate elderly presented alteration, which was partially compatible with the study of Lenardt et al. ${ }^{23}$ where the association between the fragility syndrome and the cognitive performance of 737 elderly individuals was analyzed, showing that the highest prevalence of low performance in the MMSE were observed among elderly, low-educated, female individuals. The authors also pointed out lower performance of the illiterate elderly women, who presented the lowest scores (less than 13 and between 13 and 17 points). In the evaluation of the relationship between sex and the MMSE, 24.2\% of males and $17.5 \%$ of females had altered results, noting that cognitive loss was more prevalent in males than females.

Freitas et al. ${ }^{24}$ observed a correspondence between functional capacity and language. In the present study, $11.3 \%$ of elderly individuals who had dependence on ADLs also presented language alterations. The chance of the elderly presenting the language changed is $31 \%$ higher if he is illiterate and being female increases the chance by $85 \%$. Being dependent for ADL increases by $239 \%$ the chance of having altered language outcome and presenting change in MMSE outcome has the same chance increased by more than 30 times. These results point to a link between these two variables, indicating that if an elderly person presents changes in the performance of their ADLs, they may also suffer from language changes and vice versa.

Massi et al. ${ }^{25}$ carried out a study on language and aging, whose objective was to analyze the effects that practices of autobiographical writing developed by elderly subjects can generate in their autonomy and well-being. They affirm that a speech-language work aimed at increasing literacy practices, focused on autobiographical reports, can meet the principles and proposals of healthy public policies aimed at the aging population, insofar as it promotes the autonomy and active participation of the elderly in the community, increasing the chances of experiencing healthy and successful aging.

\section{Conclusion}

Through the analysis of the functional capacity and the language of the elderly in Manaus community, it was possible to identify aspects relevant to the quality of life of these individuals with regard to their independence and effective communication. The study pointed out that being dependent for ADL increases the chance of language difficulties by $239 \%$. Considering that these aspects interfere in the quality of life, the development of strategies and actions, in the attempt to interfere in the individual lifestyle, has the potential to promote health, life preservation and recovery of diseases, so that such actions are reflected in the performance, in maintaining autonomy and independence of the elderly.

Given the social, economic and health impact, these results suggest the need to develop effective intervention programs to delay or prevent the onset of cognitive impairment in the elderly. It is worth highlighting the need for studies with larger population samples in the northern region, in order to find statistical relevance of the data and thus to be able to plan and improve the attendance to the needs and problems resulting from aging.

\section{Acknowledgements}

None

\section{Conflict of interest}

Authors declare there is no conflict of interest in composing this manuscript.

\section{References}

1. Carvalho JAM, Garcia RA. O envelhecimento da população brasileira: um enfoque demográfico. CadSaúde Públ. 2003;19(3):725-733.

2. Andrade LM, Sena ELS, Pinheiro GML, et al. Políticas públicas para pessoas idosas no Brasil: uma revisão integrativa. CiêncSaúde Coletiva. 2013;18(12):3543-3552.

3. Cervato AM, Derntl AM, Latorre MRDO. Educação nutricional para adultos e idosos: uma experiência positiva em Universidade Aberta para a Terceira Idade. RevNutr. 2005;18(1):41-52.

4. Dawalibi NW, Goulart RMM, Prearo LC. Fatores relacionados à qualidade de vida de idosos em programas para a terceira idade. Ciênc\& Saúde Coletiva. 2014;19(8):3505-3512.

5. Santos MIPO, Griep RH. Capacidade funcional de idosos atendidos em um programa do SUS em Belém (PA).Ciênc\& Saúde Coletiva. 2013;18(3):753-761

6. Bento JA, Lebrão ML. Suficiência de renda percebida por pessoas idosas no Município de São Paulo/Brasil. Ciênc\& Saúde Coletiva. 2013;18(8):2229-2238. 
7. Albuquerque AG, Oliveira GSM, Silva VL, et al. Capacidade funcional e linguagem de idosos não-participantes e participantes de grupos de intervenção multidisciplinar na atenção primária à saúde. Rev CEFAC 2012;14(5):952-962.

8. Marinho LM, Vieira MA, Costa SM, et al. Grau de dependência de idosos residentes em instituições de longa permanência. Rev Gaúcha Enferm. 2013;34(1):104-110.

9. Tubero AL. A linguagem do envelhecer: saúde e doença. Dist Comunicação. 1999;10(2):167-176.

10. Crispim KGM, Ferreira AP, Silva TL, et al. Characterization of self-reported communication disorders in elderly women living in Manaus, state of Amazonas, Brazil. Rev Bras Geriatr Gerontol. 2014;17(3):485-495.

11. Garcia FHA, Mansur LL. Habilidades funcionais de comunicação: idoso saudável. Acta Fisiátr. 2006;13(2):87-89.

12. Lima-Costa MF, Barreto SM. Tipos de estudos epidemiológicos: conceitos básicos e aplicações na área do envelhecimento. Epidemiol Serv Saúde. 2003;12(4):189-201.

13. Cauduro MHF. Estudo comparativo das condições de vida e de saúde entre idosos de Porto Alegre e Manaus. Dissertação (Mestrado em Gerontologia Biomédica). Pontifícia Universidade Católica do Rio Grande do Sul, Porto Alegre, Brazil; 2009.

14. Karsch UM. Idosos dependentes: famílias e cuidadores. CadSaúde Públ. 2003;19(3):861-866.

15. Azevedo LM, Nunes VMA, Alchieri JC. Perdas da capacidade funcional em idosos institucionalizados no município de Natal/RN.RevPesqCuid Fundam. 2014;6(2):485-492.

16. MD Mendonça, Barbosa AJG. O uso do Mini-Exame do Estado Mental em pesquisas com idosos no Brasil: uma revisão sistemática. Ciência \& Saúde Colet. 2015;20(12):3865-3876.
17. Pérez-Díaz LAG, Calero MD, González EN. Prediction of cognitive impairment in the elderly by analysing their performance in verbal fluency and in sustained attention. Rev Neurol. 2013;56(1):1-7.

18. Chin AL, Negash S, Xie S, et al. Quality, and not just quantity, of education accounts for differences in psychometric performance between African Americans and hite non-Hispanics with Alzheimer's disease. $J$ Int Neuropsychol Soc. 2012;18(2):277-285.

19. Lourenco RA, Veras RP. Mini-Exame do Estado Mental: características psicométricas em idosos ambulatoriais. RevSaúde Públ. 2006;40(4):712-719.

20. Coelho FGM, Vital TM, Novais IP, et al. Desempenho cognitivo em diferentes níveis de escolaridade de adultos e idosos ativos. Rev Bras Geriatr Gerontol. 2012;15(1):7-15.

21. Converso MER, Iartelli I. Caracterização e análise do estado mental e funcional de idosos institucionalizados em instituições públicas de longa permanência. J Bras Psiquiat. 2007;56(4):267-272.

22. Valle EA, Castro CE, Firmo JOA. Estudo de base populacional dos fatores associados ao desempenho no Mini Exame do Estado Mental entre idosos: Projeto Bambuí. CadSaúde Pública. 2009;25(4):918-926.

23. Lenardt $\mathrm{MH}$, Michel T, Wachholz PA. O desempenho de idosas institucionalizadas no miniexame do estado mental. Acta Paul Enferm. 2009;22(5):638-644.

24. Freitas RS, Fernandes MH, Coqueiro RS, et al. Capacidade funcional e fatores associados em idosos: estudo populacional. Acta Paul Enferm. 2012;25(6):933-939.

25. Massi G, Berberian AP, Guarinello AC, et al. Linguagem e envelhecimento: práticas de escrita autobiográfica junto a idosos. Rev CEFAC. 2015;17(6):2065-2071. 